\title{
Evaluation of Nueva Ecija University of Science and Technology (NEUST) Extension Services Re: Mushroom Growers of Tanawan
}

\author{
Edison S. Diego, Katrina A. Fuellos, Marissa P. Marquez, \& Perlita F. \\ Villacorta, Jennifer G. Fronda
}

\begin{abstract}
This research aimed to evaluate the NEUST extension service provided by the Business Administration (BA) Society on the members of Tanawan Mushroom Grower's Association of Barangay Tanawan, Dingalan, Aurora. Evaluation research was made to assess the current situation of the cooperative in this remote barangay.

Mushroom production is appropriate to the locality and its residents based on their economic profile, interests, and availability of resources.The climate of Barangay Tanawan also suits for mushroom growing. Likewise, mushroom growing requires little space and will not consume a lot of time of growers. The officers of the cooperative further requested that the BA Society could provide them free seeds and continuous assistance to make their association thrived in this business endeavor.
\end{abstract}

Keywords- Business Administration, development program, extension service, livelihood, mushroom production.

\section{INTRODUCTION}

Livelihood for barangay across the country is one of the basic needs of families for their everyday living. Barangays, especially those in the remote or far-flung areas need proper guidance to start up something worthy for the community, profitable for their families and learnings for the entire locality; or they may continue what they used to do bearing additional knowledge and ideas that can make their living simpler and easier.

Tanawan is NEUST's adopted barangay for its Oplan Development Program. It is a resettlement area for more than two hundred households devastated by flashfloods in 2004. Currently, Tanawan has underdeveloped road networks and backyards. It also has idle lands and structures which can be turned into something productive [1].

The BA Society of NEUST Extension Service intends for life-long barangay development by helping Barangay Tanawan's Mushroom Growers Association. Furthermore, society wants to share timely ideas that suit the community's local workforce. A place like Tanawan is strategically located in Highland with a good source of water and fertile soil that is needed for farming.

"Issues in the community, such as this case of Tanawan, will not be solely addressed by the local government officials nor by the residents, but these need a knowledge' based sector or the epistemic community and the academe for it to come up with a scientific diagnosis with regard to the occurrences of problems in the community [2]".

This study touches the Oplan Development Program of NEUST that focuses on a mission to "Transform Barangay Tanawan into economically sufficient barangay and idyllic tourist destination in Dingalan, Aurora [1]. The said study found out that Barangay Tanawan needed assistance that will ensure the development and upgrade in the quality of life of locals, particularly in terms of water safety, backyards improvement, sanitation, waste segregation, gardening and operations of small cooperatives. Likewise, they would want training on proper leadership and management risk reduction and livelihood skills [1].

The Philippine Department of Social Welfare and Development has led in the provision of opportunities for income-generating activities and livelihood development through the implementation of the Sustainable Livelihood Program since 2011. This policy note describes the program and reflects on opportunities the plan has for improving and complementing other social protection programs [3].

On the other path, barangay may form cooperative or associations to provide goods via voluntary membership. In a news article published by The New Times in Rwanda, cooperative members were all grateful that they took a risk in forming cooperative that engaged in mushroom farming. The group made up of 25 members, 19 women, and six men, produces about 1.5 tons of fresh mushroom per month or about $400 \mathrm{~kg}$ weekly. The project has significantly boosted members' financial muscle, as well as nutritional 
levels of their families. The co-operative sells the mushrooms to a dealership and processor of mushrooms. Cooperative members say mushroom growing has considerably changed members' lives, especially by improving their household income and nutrition levels [4].

Mushroom growing requires little space and time, and farmers can make use of their rice straws following harvesting. Mushroom can be grown the whole year round provided proper storage of rice straw is prepared. Mushroom has been attracting the attention of mankind since ancient times and use of mushroom, as food is as old as human civilization. It is very rich in protein, vitamins, and minerals. Unfortunately, it is realized that mushrooms did not receive universal acceptance over the years since several naturally growing mushrooms are poisonous. Now the situation has been changed because the cultivated edible mushrooms are safe for human consumption [5].
The current study intended to determine the situation of mushroom production and problems encountered by mushroom growers of Barangay Tanawan. The findings helped the researchers to develop an intervention program that will benefit the association.

\section{MATERIALS AND METHODS}

This study utilized evaluation research and a survey questionnaire adopted from NEUST Graduate School as the main instrument of this study. According to [6] as cited in [7] "evaluation research focuses on assessing a particular practice or intervention at a given site." The researchers conducted a series of observation and site visitation as well as focus group discussion to get the necessary information with the used of the questionnaire regarding the concerns and profiles of Tanawan Mushroom Grower's Association.

\section{A. Personal Profile}

\section{RESULTS AND DISCUSSION}

Table 1.1.Demographics

\begin{tabular}{|c|c|c|c|c|c|c|c|c|c|c|c|c|c|c|c|}
\hline \multirow{2}{*}{ Particulars } & \multicolumn{5}{|c|}{ Age } & \multicolumn{2}{|c|}{ Gender } & \multicolumn{4}{|c|}{ Civil Status } & \multicolumn{4}{|c|}{ Educational Attainment } \\
\hline & 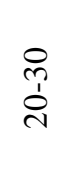 & $\frac{\stackrel{f}{+}}{m}$ & $\frac{\stackrel{0}{n}}{7}$ & $\frac{8}{0}$ & $\begin{array}{l}7 \\
0 \\
0 \\
0 \\
0\end{array}$ & $\frac{0}{\sum^{\pi}}$ & 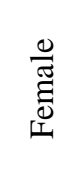 & $\begin{array}{l}\stackrel{0}{00} \\
\stackrel{\Xi}{\Xi}\end{array}$ & $\frac{\vec{D}}{\stackrel{D}{E}}$ & 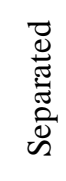 & $\begin{array}{l}0 \\
0 \\
0 \\
0 \\
0 \\
3 \\
3\end{array}$ & 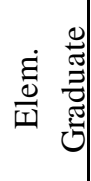 & 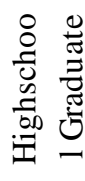 & 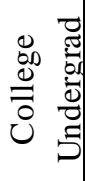 & $\begin{array}{l}\stackrel{0}{\infty} \\
\stackrel{0}{0} \\
\stackrel{0}{0}\end{array}$ \\
\hline Frequency & 12 & 18 & 17 & 11 & 9 & 30 & 37 & 8 & 45 & 6 & 8 & 24 & 28 & 6 & 9 \\
\hline Percentage & $\begin{array}{l}18 \\
\%\end{array}$ & $\begin{array}{l}27 \\
\%\end{array}$ & $\begin{array}{l}25 \\
\%\end{array}$ & $\begin{array}{l}17 \\
\%\end{array}$ & $\begin{array}{l}13 \\
\%\end{array}$ & $\begin{array}{l}45 \\
\%\end{array}$ & $\begin{array}{l}55 \\
\%\end{array}$ & $\begin{array}{l}12 \\
\%\end{array}$ & $\begin{array}{l}67 \\
\%\end{array}$ & $9 \%$ & $\begin{array}{l}12 \\
\%\end{array}$ & $\begin{array}{l}36 \\
\%\end{array}$ & $\begin{array}{l}42 \\
\%\end{array}$ & $9 \%$ & $\begin{array}{l}13 \\
\%\end{array}$ \\
\hline Total & & & $=10$ & & & $67=$ & $00 \%$ & & $67=$ & $00 \%$ & & & 67 & $100 \%$ & \\
\hline
\end{tabular}

Based on the gathered data, the majority of the head of the family in Tanawan aged 31-50, mostly female and high school and elementary graduates.

Table 1.2. Income Profile

\begin{tabular}{|c|c|c|c|c|c|c|c|c|c|c|c|c|c|c|c|c|}
\hline \multirow[b]{2}{*}{ Particular } & \multicolumn{4}{|c|}{ Occupation } & \multicolumn{12}{|c|}{ Other Sources of Income } \\
\hline & 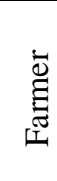 & $\frac{8}{\stackrel{0}{2}}$ & 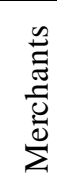 & $\stackrel{0}{0}$ & 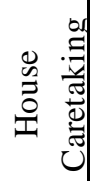 & 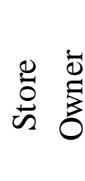 & 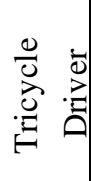 & 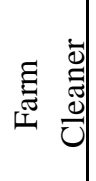 & $\frac{\frac{\pi}{0}}{\overline{0}}$ & 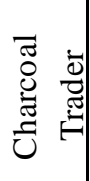 & $\begin{array}{ll}\overline{0} & \overline{0} \\
\stackrel{0}{0} & \overline{0} \\
\sim & >\end{array}$ & 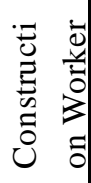 & 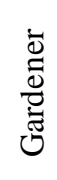 & $\underset{\frac{1}{5}}{\frac{1}{2}}$ & $\begin{array}{l}\frac{y}{0} \\
0 \\
0 \\
0 \\
0 \\
0\end{array}$ & 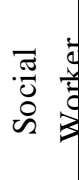 \\
\hline Frequency & 10 & 25 & 23 & 9 & 1 & 6 & 9 & 1 & 1 & 1 & 4 & 4 & 6 & 2 & 31 & 2 \\
\hline Percentage & $\begin{array}{l}15 \\
\%\end{array}$ & $\begin{array}{l}37 \\
\%\end{array}$ & $\begin{array}{l}35 \\
\%\end{array}$ & $\begin{array}{l}13 \\
\%\end{array}$ & \multirow{2}{*}{\multicolumn{12}{|c|}{$\begin{array}{l}* 38 \text { samples have other sources of income equivalent to } 57 \% \text { of the total } \\
\text { population }\end{array}$}} \\
\hline Total & & 6 & 100 & & & & & & & & & & & & & \\
\hline
\end{tabular}

Head of the households was mostly engaged in merchandising and entrepreneurship. This indicates that the majority of the bracket is appropriate in business venture interested and eager to do business for a living.

B. Economic Profile

Table 2. Economic Profile of Tanawan Residents 


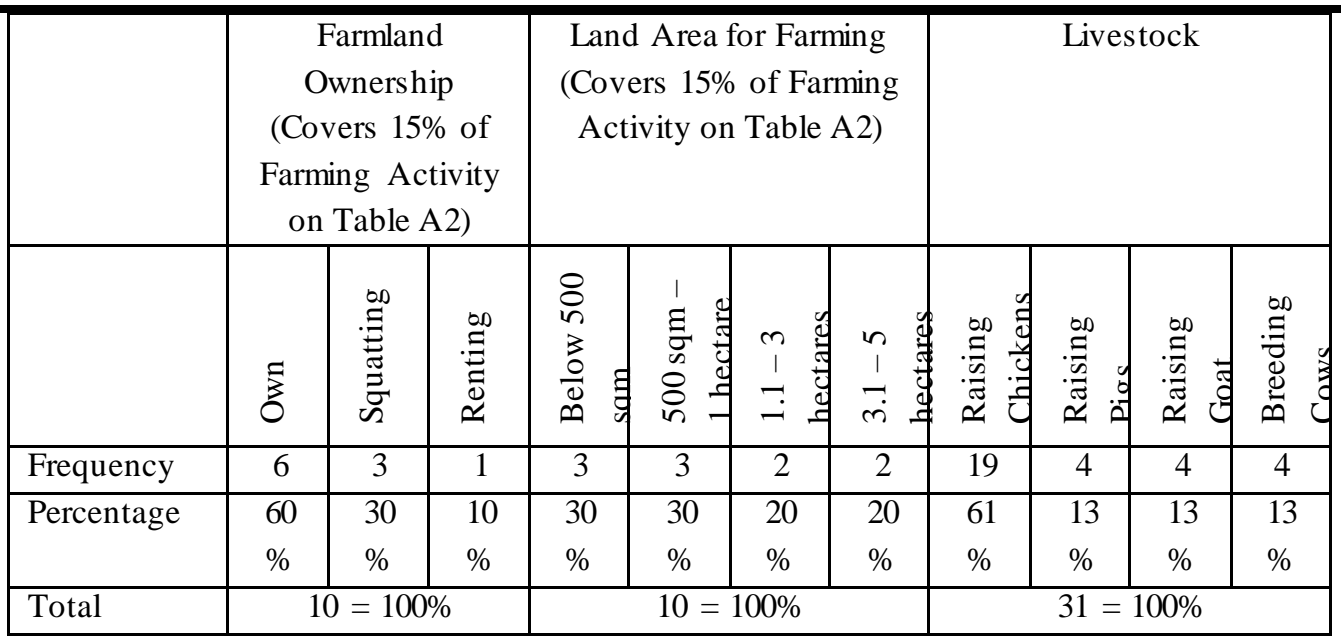

With a vast land, only $15 \%$ of the population is engaged in farming, wherein $60 \%$ of it owns the property their cultivating. Thirty-one households are into raising live stocks; mostly raising chickens covering $61 \%$ of the population.

\section{Property and Availability of Resources Profile}

Table 3. Property and Availability of Resources of Tanawan Residents

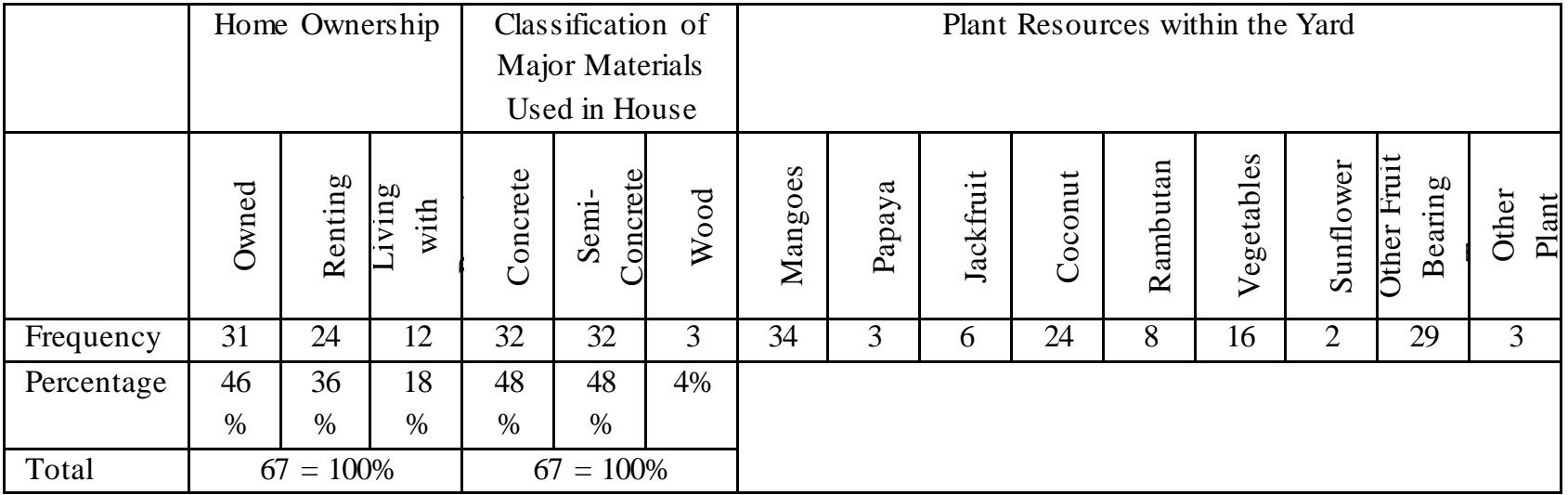

On property assessment, fewest of the household owned house and lot in the barangay mostly concreted houses; they have various plants and fruit-bearing trees like Mango and Coconut in their yards.

\section{Problems Encountered}

Table 4. Problems Encountered by Tanawan Mushroom Growers Association

\begin{tabular}{|c|l|c|c|}
\hline Rank & \multicolumn{1}{|c|}{ Problems Encountered } & Frequency & Percentage \\
\hline 1 & Lack of expertise to generate the product & 67 & $100 \%$ \\
\hline 2 & No market (sure market) for the product. & 54 & $81 \%$ \\
\hline 3 & Lack of assistance from the Local Government Unit (LGU). & 34 & $51 \%$ \\
\hline 4 & Lack of transportation. & 32 & $48 \%$ \\
\hline 5 & No internet access. & 15 & $22 \%$ \\
\hline
\end{tabular}

It was found out that the highest problem of the association is expertise in generating their product. Companies that don't offer quality training to new and current employees harm not only the development of individual workers but also the evolution of the business itself [8]. Regards to this problem skills and knowledge of every member must be accelerated for the cooperative's sake.
A business owner must always be thinking in terms of supply and demand[9]. The demand and attitude of the buyer may contribute to the sales of the business. The failure to study the behavior of the target market will bring the business down. Even though they know about selling, they were not confident about their strategies on how to be an entrepreneur and to make a profit in a sustainable and 
efficient way. One more factor, it is a far-flung area difficult for the LGU to reach out. Other problems in the area include logistics, promotion, and internet access.

\section{E. DEVELOPMENT PROGRAM}

The culture of mushroom growing is gaining popularity in the Philippines[5]. Mushroom Cultivation can also be a feasible livelihood activity [10]. Its present cultivation in this country is limited, perhaps due to insufficiency of planting materials and the limited local knowledge about its culture. Mushroom Cultivation can help reduce vulnerability to poverty and strengthens livelihood through the generation of the fast yielding nutritious source of food and reliable source of income [10]. Mushroom is a delicacy and is accepted as a vegetable.

Mushroom production is the solution for the problems encountered in Garden Tourism [1] after the said assessment in Barangay Tanawan. The NEUST presented activities like seminar-workshop on mushroom growing [1] (\# 4), and mushroom growing and marketing [10] (\#8) to solve the problems in Garden Tourism. As a response to that proposed activity, the NEUST Graduate School B.A. Society provided quality mushroom fruiting bags and a focus group discussion regarding the marketing strategy on how to market and sell the product.

\section{CONCLUSIONS AND RECOMMENDATIONS}

Mushroom production is appropriate to the locality and its residents based on their economic profile, interests, and availability of resources. The climate of Barangay Tanawan also suits for mushroom growing. To add, mushroom growing requires little space and will not consume a lot of time of growers. The officers of the cooperative further requested that the BA Society could provide them free seeds and continuous assistance to make their as sociation thrived in this business endeavor.

It is highly recommended an excessive training toward doing business in partnership with LGU and DTI for entrepreneurship awareness and to be able to make accurate decisions[11] for proper Mushroom products pricing, BFAD, DOST and TESDA for food processing and mushroom production.

Likewise, the existing cooperative and barangay officials should work hand in hand in studying and exploring the performance [12] of their mushroom in the market to enhance their on-going livelihood project further. To make the product of Tanawan to be known outside their place, participation to trade fair sponsored by the DTI every month should be encouraged.

Furthermore, the barangay needs sustainable platforms to support group that is willing to give aides for their community development, not just in livelihood; it can be on education, sanitation, barangay management, or touris $m$.

Table 5 B.A. Society Extension Program: Intervention Program on Mushroom Production in Tanawan Dingalan Aurora

\begin{tabular}{|c|c|c|c|c|c|}
\hline Program & Status & Resources Needed & Hindrance & Intervention & Benefits \\
\hline $\begin{array}{l}\text { 1.Implementation of } \\
\text { Mushroom Production }\end{array}$ & Ongoing & $\begin{array}{c}\text { 1.Service Vehicle } \\
\text { 2.Barangay Captain } \\
\text { Assistance } \\
\text { 3.Tanawan Residents } \\
\text { 4.B.A. Society Officers } \\
\text { and Advisers }\end{array}$ & $\begin{array}{l}\text {-Different } \\
\text { interests of the } \\
\text { residents } \\
\text { - Time } \\
\text { Management }\end{array}$ & $\begin{array}{c}\text {-The } \\
\text { Association } \\
\text { should } \\
\text { participate in } \\
\text { the } \\
\text { implementation } \\
\text { of the program. }\end{array}$ & $\begin{array}{l}\text { A well- } \\
\text { implemented plan } \\
\text { will raise profit for } \\
\text { the as sociation. The } \\
\text { members further } \\
\text { developed their } \\
\text { skills in mushroom } \\
\text { production }\end{array}$ \\
\hline 2.Site Visitation & $\begin{array}{c}\text { First } \\
\text { Week } \\
\text { June } 2019\end{array}$ & $\begin{array}{c}\text { 1.Service Vehicle } \\
\text { 2.Barangay Captain } \\
\text { Assistance } \\
\text { 3.Mushroom Production } \\
\text { Area }\end{array}$ & $\begin{array}{l}\text {-The } \\
\text { production } \\
\text { area is far } \\
\text { from the } \\
\text { barangay hall. } \\
\text {-Ongoing } \\
\text { Renovation } \\
\text { and Building }\end{array}$ & $\begin{array}{l}\text { - } \\
\text { Communication } \\
\text { with the } \\
\text { Barangay } \\
\text { Officials for } \\
\text { Assistance and } \\
\text { Guidance going } \\
\text { to the site. } \\
\text {-Monitoring of }\end{array}$ & $\begin{array}{l}\text {-Observation must } \\
\text { be more efficient of } \\
\text { the actual, and real } \\
\text { production area } \\
\text { must be seen. } \\
\text {-Mushroom is food } \\
\text { for consumption, so } \\
\text { sanitation must be } \\
\text { maintained and }\end{array}$ \\
\hline
\end{tabular}




\begin{tabular}{|c|c|c|c|c|c|}
\hline & & & $\begin{array}{l}\text { of Mushroom } \\
\text { Production } \\
\text { Area, } \\
\text { sanitation } \\
\text { must be } \\
\text { observed }\end{array}$ & $\begin{array}{l}\text { the cleanliness ( } \\
\text { Cleaning and } \\
\text { maintenance } \\
\text { should be } \\
\text { scheduled and } \\
\text { monitored for } \\
\text { the site } \\
\text { cleanliness. }\end{array}$ & always observed. \\
\hline $\begin{array}{c}\text { 6.Mushroom Production } \\
\text { Seminar }\end{array}$ & $\begin{array}{c}\text { Second } \\
\text { Week } \\
\text { June } \\
2019\end{array}$ & $\begin{array}{c}\text { 1.Barangay Official } \\
\text { Support } \\
\text { 2.Mushroom Growers } \\
\text { from San Ildefonso } \\
\text { Bulacan } \\
\text { 3.B.A. Society Officers } \\
\text { and Advisers } \\
\text { 4.Tanawan Mushroom } \\
\text { Grower Members and } \\
\text { other residents }\end{array}$ & $\begin{array}{l}\text {-The } \\
\text { mushroom } \\
\text { growers } \\
\text { priority in } \\
\text { everyday life. } \\
\\
\text {-The resource } \\
\text { speaker place } \\
\text { is distant to } \\
\text { the seminar } \\
\text { venue }\end{array}$ & $\begin{array}{l}\text {-Giving letters } \\
\text { and } \\
\text { announcement } \\
\text { ahead of time } \\
\text { to the } \\
\text { mushroom } \\
\text { growers } \\
\text { regarding the } \\
\text { planned } \\
\text { seminar } \\
\text {-Having an } \\
\text { agreement with } \\
\text { the resource } \\
\text { speaker ( free } \\
\text { seminar in } \\
\text { return to the } \\
\text { marketing of } \\
\text { his/her product. }\end{array}$ & $\begin{array}{c}\text {-Being } \\
\text { knowledgeable } \\
\text { about the different } \\
\text { strategy of } \\
\text { mushroom } \\
\text { production can } \\
\text { drive the } \\
\text { motivation of } \\
\text { members to work } \\
\text { more for the } \\
\text { growth of the } \\
\text { cooperative. }\end{array}$ \\
\hline $\begin{array}{c}\text { 7.Mushroom Processing } \\
\text { Seminar }\end{array}$ & $\begin{array}{c}\text { First } \\
\text { Week } \\
\text { August } \\
2019\end{array}$ & $\begin{array}{c}\text { 1.Barangay Officials } \\
\text { 2.DTI } \\
\text { 3.BFAD } \\
\text { 4.Cooperative Members } \\
\text { 5.B.A. Society Officers } \\
\text { and Members }\end{array}$ & $\begin{array}{c}\text {-Lack of } \\
\text { Mushroom } \\
\text { Surplus } \\
\\
\text {-Losses on the } \\
\text { start of the } \\
\text { mushroom } \\
\text { processing } \\
\text { activity }\end{array}$ & $\begin{array}{l}\text {-Conduct } \\
\text { training } \\
\text { regarding the } \\
\text { culturing } \\
\text { /making of } \\
\text { Mushroom } \\
\text { fruiting bag for } \\
\text { fewer expenses. } \\
\text {--Small losses } \\
\text { are tolerable } \\
\text { from the start } \\
\text { of processing. }\end{array}$ & $\begin{array}{l}\text {-Harvest Surplus } \\
\text { can be a motivation } \\
\text { to process } \\
\text { mushroom into } \\
\text { another product, for } \\
\text { more income and } \\
\text { more product line } \\
\text { for the target } \\
\text { market. }\end{array}$ \\
\hline $\begin{array}{l}\text { 8.Mushroom Marketing } \\
\text { Management Seminar }\end{array}$ & $\begin{array}{c}\text { Second } \\
\text { Week } \\
\text { August } \\
2019\end{array}$ & $\begin{array}{l}\text { 1.B.A. Society Members } \\
\text { (from the Industry), } \\
\text { Officers and Advisers } \\
\text { 2.Mushroom Cooperative } \\
\text { Members }\end{array}$ & $\begin{array}{l}\text {-Lack of } \\
\text { confidence of } \\
\text { some } \\
\text { mushroom } \\
\text { members } \\
\text { regarding their } \\
\text { product. }\end{array}$ & $\begin{array}{l}\text {-Educating the } \\
\text { members about } \\
\text { the biggest } \\
\text { possibility of } \\
\text { their product, } \\
\text { especially when } \\
\text { develop. } \\
\text {-Monitoring } \\
\text { regularly must } \\
\text { be applied. }\end{array}$ & $\begin{array}{c}\text { Good Marketing } \\
\text { Management about } \\
\text { the Mushroom will } \\
\text { keep the } \\
\text { cooperative exists } \\
\text { and grow for a long } \\
\text { period. }\end{array}$ \\
\hline
\end{tabular}




\begin{tabular}{|c|c|c|c|c|c|}
\hline $\begin{array}{l}\text { 9.Product Exposure } \\
\text { (Aurora Province- } \\
\text { Pasalubong Centers) } \\
\text { - Different products out } \\
\text { of the mushroom }\end{array}$ & $\begin{array}{c}\text { Last week } \\
\text { of } \\
\text { November } \\
2019\end{array}$ & $\begin{array}{cc}\text { 1. } & \text { Mushroom } \\
\text { Growers } \\
\text { Cooperative } \\
\text { 2. } \\
\text { 3. } \\
\text { 2GI Aurora } \\
\text { 4. Aurora } \\
\text { NEUST- B.A. } \\
\begin{array}{c}\text { Society Officers } \\
\text { and Advisers }\end{array}\end{array}$ & $\begin{array}{l}\text { - The pressure } \\
\text { on the side of } \\
\text { the members } \\
\text { on how to } \\
\text { introduce the } \\
\text { product to the } \\
\text { market or the } \\
\text { whole } \\
\text { province. } \\
\text {-Different } \\
\text { demands or } \\
\text { interest in the } \\
\text { market. }\end{array}$ & $\begin{array}{l}\text { - Reminding } \\
\text { the confidence } \\
\text { learned on the } \\
\text { marketing } \\
\text { management } \\
\text { seminar } \\
\text { - Value adding } \\
\text { on the benefits } \\
\text { and uses of the } \\
\text { mushroom to } \\
\text { the target } \\
\text { market. }\end{array}$ & $\begin{array}{l}\text { - Product exposure } \\
\text { will help } \\
\text { mushroom growers } \\
\text { to introduce and } \\
\text { showcase their } \\
\text { product to the } \\
\text { market. }\end{array}$ \\
\hline $\begin{array}{c}\text { 10. Sustainable/ } \\
\text { Continues } \\
\text { Mushroom } \\
\text { Production } \\
\text { Monitoring and } \\
\text { Evaluation }\end{array}$ & $\begin{array}{c}\text { First week } \\
\text { December } \\
2019\end{array}$ & $\begin{array}{c}\text { 1. } \begin{array}{c}\text { Mushroom } \\
\text { Growers }\end{array} \\
\text { 2. NEUST -B.A. } \\
\text { Society officers } \\
\text { and Advisers }\end{array}$ & $\begin{array}{c}\text {-Hardship in } \\
\text { the availability } \\
\text { of time of both } \\
\text { parties. } \\
\text {-LGU support } \\
\text { in the growing } \\
\text { mushroom } \\
\text { production }\end{array}$ & $\begin{array}{l}\text { - Setting up a } \\
\text { time chart } \\
\text { about the } \\
\text { quarterly visit } \\
\text { and checking of } \\
\text { inventory } \\
\text { logbooks } \\
\text { - Formal letter } \\
\text { request about } \\
\text { the needed } \\
\text { support from } \\
\text { the government } \\
\text { unit. }\end{array}$ & $\begin{array}{l}\text { - Monitoring and } \\
\text { evaluation were } \\
\text { performed for the } \\
\text { cooperative to stay } \\
\text { and to grow as time } \\
\text { goes by and to } \\
\text { prevent business } \\
\text { closure. }\end{array}$ \\
\hline
\end{tabular}

\section{REFERENCES}

[1] Zabala, Bernardo Jr., Guiterrez, Manuela, \&Subia, Gener. (2018) Needs Assessment of Barangay Tanawan, Dingalan, Aurora towards a Proposed Oplan Development Program. International Journal of Environment, Agriculture and Biotechnology (IJEAB) Volume 3, Is sue 6

[2] Dilao, Anilou B. (2019).Impact of community extension program on the residents of barangay CatadmanManabay, La Salle University.

[3] THE WORLD BANK.(2018).The Philippines Sustainable Livelihood Program: Providing and Expanding Access to Employment and Livelihood Opportunities

[4] The NEW TIMES REPORTER.(2015). Mushroom Growing Transform Lives of Kanyinya Women, The New Times-Rwanda

[5] PINOYBUSINESS.COM, Mushroom Production Guide (2016).

[6] Powell, R. (2006). Evaluation Research: An Overview. Library Trends, 55,102-120.

[7] Subia, G.S. (2018). Comprehensible Technique in Solving Consecutive Number Problems in Algebra.
Journal of Applied Mathematics and Physics, 6,447-457. https://doi.org/10.4236/jamp.2018.63041

[8] Petersen, Lainie and Thompson, Jayne. (March 6, 2019) The effects of Lack of employee training.

[9] Dowell, Derek. (2019). How supply and Demand Impacts Decision in Business

[10] MARSHALL ELAINE, TAN, N.G. (2009) Make Money by Growing Mushrooms Elaine Marshall and N. G(Tan) Nair Rural Infrastructure and Agro-Industries Division Food and Agriculture Organization of the United Nations Rome.

[11] [11] Subia, Gener S. (2018). Think Like My Teacher (TLMT): A New Method in Assessing Millennial Learners. International Journal of Arts, Humanities and Social Sciences.Volume 3. Issue 1.www.ijahss.com Q q

[12] [12] Subia, G. , Amaranto, J. , Amaranto, J. , Bustamante, J. and Damaso, I. (2019) Chess and Mathematics Performance of College Players: An Exploratory Analysis. Open Access Library Journal, 6, 1-7. doi: 10.4236/oalib.1105195 